\title{
TINJAUAN YURIDIS TINDAK PELANGGARAN USAHA PERASURANSIAN MENURUT UNDANG-UNDANG NOMOR 40 TAHUN 2014 TENTANG PERASURANSIAN
}

\author{
Suisno, SH, M.Hum
}

\begin{abstract}
Abstrak
Tujuan dilakukan penelitian ini adalah untuk mengetahui Pengaturan Usaha Perasuransian dan untuk mengetahui sanksi hukum terhadap pelaku tindak pelanggaran usaha perasuransian menurut undang-undang nomor 40 tahun 2014 tentang Perasuransian. Type penelitian hukum yang dilakukan adalah yuridis normative (hukum normatif). Sedangkan masalah pendekatan yang digunakan dalam penelitian ini adalah pendekatan undang-undang (statue approach) selain itu juga digunakan pendekatan khusus (case approach) yaitu digunakan untuk melihat khasus-khasus pelanggaran Usaha Perasuransian. Berdasarkan hasil penelitian bahwa Pengaturan Usaha Perasuransian yang dimuat dalam undang-undang Nomor 40 tahun 2014 Tentang Perasuransian yang ditunjuknya Otoritas Jasa Keuangan (OJK) sebagai lembaga negara yang memiliki kuasa penuh dalam menjalankan fungsi dan pengawasan, diharapkan dapat membuat kebijakan terhadap perasuransian yang dapat membawa perasuransian menjadi lebih berkembang di masa depan dan dapat bersaing dengan negara-negara maju dalam dunia asuransi. Sedangkan Sanksi hukum terhadap pelaku tindak pelanggaran usaha perasuransian menurut Undang-undang Nomor 40 Tahun 2014 tentang Perasuransian yakni, jika usaha perasuransian melakukan pelanggaran terhadap ketentuan undang-undang atau peraturan dalam pelaksanaannya maka Otoritas Jasa Keuangan (OJK) berwenang melakukan tindakan berupa pemberian peringatan, pembatasan kegiatan usaha, larangan untuk memasarkan produk asuransi, memberi sanksi-sanksi pidana hingga pada pencabutan izin usaha.
\end{abstract}

Kata Kunci : Hukum Pidana, Penegakan Hukum, Pelanggaran Usaha Perasuransian.

\section{A. PENDAHULUAN}

Pembangunan nasional memerlu-kan dan mengharuskan dilakukannya penyesuaian dalam berbagai hal terhadap perkembangan kondisi dan aspirasi masyarakat. Dalam industri perasuransian, baik secara nasional maupun global, terjadi perkembangan yang pesat yang ditandai dengan meningkatnya volume usaha dan bertambahnya pemanfaatan layanan jasa perasuransian oleh masyarakat. Layanan jasa perasuransian pun semakin bervariasi sejalan dengan perkembangan kebutuhan masyarakat akan pengelolaan risiko dan pengelolaan investasi yang semakin tidak terpisahkan, baik dalam kehidupan pribadi maupun dalam kegiatan usaha.
"Asuransi adalah perjanjian antara dua pihak, yaitu perusahaan asuransi dan pemegang polis, yang menjadi dasar bagi penerimaan premi oleh perusahaan asuransi sebagai imbalan untuk:

a. Memberikan penggantian kepada tertanggung atau penanggung polis karena kerugian, kerusakan, biaya yang timbul, kehilangan keuntungan, atau tanggung jawab hukum kepada pihak ketiga yang mungkin diderita tertanggung atau pemegang polis karena terjadinya suatu peristiwa yang tidak pasti; atau

b. Memberikan pembayaran yang didasarkan pada meninggalnya tertanggung atau pembayaran yang didasarkan pada hidupnya tertanggung dengan manfaat yang besarnya telah ditetapkan dan/atau 
didasarkan pada hasil pengelolaan dana. (UU No.40 tahun 2014 tentang Perasuransian, Pasal. 1, ayat. 1)".

"Usaha perasuransian adalah segala usaha menyangkut jasa pertanggungan atau pengelolaan resiko, pertanggungan ulang resiko, pemasaran dan distribusi produk asuransi atau produk asuransi syariah, atau penilaian kerugian asuransi atau asuransi syariah. (UU No.40 tahun 2014 tentang Perasuransian, Pasal. 1, ayat. 2)."

Setiap pihak yang melakukan usaha perasuransian wajib terlebih dahulu mendapat izin usaha dari otoritas jasa keuangan (OJK). Izin usaha merupakan hal yang mendasar dari setiap perusahaan asuransi. Untuk mendapatkan izin usaha dari Menteri Keuangan perusahaan perasuransian harus mengajukan permohonan izin usahanya dengan memenuhi persyaran dan tata cara yang telah ditentukan. Persyaratan tersebut antara lain bentuk hukum, deposito wajib, tenaga ahli, program kerja dan lain-lainnya.

Pada dasarnya fungsi utama dari asuransi adalah sebagai mekanisme pengalihan/transfer resiko atau risk transfer mechanism, yaitu mengalihkan resiko dari satu pihak yaitu tertanggung kepada pihak lain yaitu penanggung. Pengalihan resiko ini tidak berarti menghilangkan kemungkinan misfortune, melainkan pihak penanggung menyediakan fasilitas pengamanan keuangan atau financial security serta ketenangan atau peace of mind bagi tertanggung. Sebagai imbalannya, maka tertanggung wajib membayarkan premi dalam jumlah yang relatif kecil bila dibandingkan dengan potensi kerugian yang mungkin akan alaminya.

Namun fungsi utama asuransi tersebut saat ini disalah gunakan oleh banyak oknumoknum yang tidak bertanggung jawab, mengaku sudah berbadan hukum dan memiliki izin usaha perasuransian padahal kenyataannya ilegal, sehingga uang yang diasuransikan raib dibawa kabur oleh pihak yang mengaku jasa perasuransian.
Hal tersebut dapat terjadi karena minimnya pengetahuan masyarakat tentang perasuransian sehingga mudah tergoda dengan janji-janji serta jaminan dari pihak usaha asuransi yang berlipat ganda. Maraknya usaha perasuransian tanpa memiliki izin usaha, sangatlah meresahkan masyarakat dan agen perasuransian yang sudah mempunyai izin usaha perasuransian, mereka sama-sama merasa dirugikan.

Adapun pokok permasalahan dalam hal ini adalah : Bagaimana pengaturan usaha perasuransian menurut undang-undang nomor 40 tahun 2014 tentang Perasuransian, Bagaimana sanksi hukum terhadap pelaku tindak pelanggaran usaha perasuransian menurut undang-undang nomor 40 tahun 2014 tentang Perasuransian.

Tujuan penelitian ini untuk mengetahui pengaturan usaha perasuransian menurut undang-undang nomor 40 tahun 2014 tentang Perasuransian dan untuk mengetahui sanksi hukum terhadap pelaku tindak pelanggaran usaha perasuransian menurut undang-undang nomor 40 tahun 2014 tentang Perasuransian.

Jenis penelitian yang digunakan adalah yuridis normatif, metode penelitian hukum normatif adalah suatu prosedur penelitian ilmiah untuk menemukan kebenaran berdasarkan logika keilmuan hukum dari sisi normatif ${ }^{33}$.

Metode pendekatan yang digunakan dalampenulisan ini adalah pendekatan perundang-undangan (Statute Approach). Pendekatan tersebut melakukan pengkajian pengaturan perundang-undangan yang berhubungan dengan pokok permasalahan. ${ }^{34}$ Selain itu juga digunakan pendekatan analisis (Analitical Approach), pendekatan ini maksudnya menganalisa sanksi hukum terhadap pelaku tindak pelanggaran usaha

${ }^{33}$ Johnny Ibrahim, Teori dan Metodologi Penelitian hukum Normatif, cetakan ke enam,Bayumedia Publishing, Malang 2012. Hal 57

34 Peter Mahmud Marzuki. Penelitian Hukum. Universitas Air Langga. Surabaya. 2005. h.96 
perasuransian menurut undang - undang nomor 40 tahun 2014 tentang Perasuransian.

\section{B. METODE PENELITIAN}

Dalam pengumpulan bahan hukum penulis menggunakan studi dokumen atau bahan pustaka dalam penulisan skripsi ini. Pengumpulan terhadap bahan-bahan hukum primer, maupun bahan hukum sekunder dikumpulkan untuk menjawab permaslahan dalam skripsi ini adalah semua bahan-bahan hukum yang berkaitan dengan Pengaturan Hukum mengenai Usaha Perasuransian.

Langkah-langkah yang berkaitan dengan pengolahan terhadap bahan hukum yang telah dikumpulkan untuk menjawab isu hukum yang telah dirumuskan dalam rumusan masalah. Tentu juga menyangkut kegiatan penalaran ilmiah terhadap bahan-bahan hukum yang di analisis, baik menggunakan induksi, deduksi, maupun abduksi. ${ }^{35}$

\section{HASIL PENELITIAN DAN PEM- BAHASAN}

Dari penelitian yang dilakukan di dapat hasil sebagai berikut :

1. Pengaturan Usaha Perasuransian yang dimuat dalam undang-undang Nomor 40 tahun 2014 Tentang Perasuransian, serta di tunjuknya Otoritas Jasa Keuangan (OJK) sebagai lembaga negara yang memiliki kuasa penuh dalam menjalankan fungsi dan pengawasan diharapkan dapat membuat kebijakan terhadap perasuransian yang dapat membawa perasuransian menjadi lebih berkembang di masa depan dan dapat bersaing dengan negara-negara maju dalam dunia asuransi.

2. Sanksi hukum terhadap pelaku tindak pelanggaran usaha perasuransian menurut Undang-undang Nomor 40 Tahun 2014 tentang Perasuransian atas dasar hal tersebut maka pengaturan sanksi sangatlah

\footnotetext{
${ }^{35}$ Ibid. h. 297.
}

jelas, jika usaha perasuransian melakukan pelanggaran terhadap ketentuan undangundang atau peraturan dalam pelaksanaannya maka Otoritas Jasa Keuangan (OJK) berwenang melakukan tindakan berupa pemberian peringatan, pembatasan kegiatan usaha, larangan untuk memasarkan produk asuransi, memberi sanksi-sanksi pidana hingga pada pencabutan izin usaha.

Asuransi adalah perjanjian antara dua pihak, yaitu perusahaan asuransi dan pemegang polis, yang menjadi dasar bagi penerimaan premi oleh perusahaan asuransi sebagai imbalan untuk:

a. Memberikan penggantian kepada tertanggung atau penanggung polis karena kerugian, kerusakan, biaya yang timbul, kehilangan keuntungan, atau tanggung jawab hukum kepada pihak ketiga yang mungkin diderita tertanggung atau pemegang polis karena terjadinya suatu peristiwa yang tidak pasti; atau

b. Memberikan pembayaran yang didasarkan pada meninggalnya tertanggung atau pembayaran yang didasarkan pada hidupnya tertanggung dengan manfaat yang besarnya telah ditetapkan dan/atau didasarkan pada hasil pengelolaan dana. (UU No.40 tahun 2014 tentang Perasuransian, Pasal. 1, ayat. 1).

Sedangkan menurut Undang-undang No.40 tahun 2014 tentang Perasuransian, Pasal. 1, ayat. 2 yaitu:

Usaha perasuransian adalah segala usaha menyangkut jasa pertanggungan atau pengelolaan resiko, pertanggungan ulang resiko, pemasaran dan distribusi produk asuransi atau produk asuransi syariah, atau penilaian kerugian asuransi atau asuransi syariah.

Berbicara mengenai Tujuan asuransi, tujuan asuransi meliputi tujuan pengalihan resiko, tujuan pembayaran ganti kerugian, tujuan pembayaran santunan, tujuan kesejahteraan anggota. Asuransi bagi masyarakat selain untuk memberikan kenyamanan, juga ada sisi lain yang ingin dicapai, yakni pemupukan dana bagi negara. 
Dana yang terkumpul dapat dipergunakan untuk biaya pembangunan nasional yang sedang dilaksanakan dalam berbagai sektor. Tampaknya disinilah tantangan lembaga asuransi sebagai pengelola risiko yang dialihkan oleh masyarakat, yang tentunya ada biaya yang harus dikeluarkan oleh masyarakat yang lebih dikenal dengan premi, pihak asuransi harus memenuhi janjinya secara jujur.

Setiap Pihak yang melakukan Usaha Perasuransian wajib terlebih dahulu mendapat izin usaha dari Otoritas Jasa Keuangan (OJK). Berdasarkan (Undang-undang No.40 Tahun 2014 tentang Perasuransian Pasal 8; Ayat 2), untuk mendapatkan izin usaha harus dipenuhi persyaratan mengenai:

a. Anggaran dasar;

b. Susunan organisasi;

c. Modal disetor;

d. Dana Jaminan; kepemilikan;

e. Kelayakan dan kepatutan pemegang saham dan Pengendali;

f. Kemampuan dan kepatutan direksi dan dewan komisaris, atau yang setara dengan direksi dan dewan komisaris pada badan hukum berbentuk koperasi atau usaha bersama sebagaimana dimaksud dalam Pasal 6 ayat (1) huruf c, dewan pengawas syariah, aktuaris perusahaan, dan auditor internal;

g. Tenaga ahli;

h. Kelayakan rencana kerja;

i. Kelayakan sistem manajemen risiko;

j. Produk yang akan dipasarkan;

k. Perikatan dengan pihak terafiliasi apabila ada dan kebijakan pengalihan sebagian fungsi dalam penyelenggaraan usaha;

1. Infrastruktur penyiapan dan penyampaian laporan kepada otoritas jasa keuangan;

m. Konfirmasi dan otoritas pengawas di negara asal pihak asing, dalam hal terdapat penyertaan langsung pihak asing; dan

n. Hal lain yang diperlukan untuk mendukung pertumbuhan usaha yang sehat.

Dalam pelaksanaan pembangunan dapat terjadi berbagai ragam dan jenis risiko yang perlu ditanggulangi oleh masyarakat, bahwa usaha perasuransian yang sehat merupakan salah satu upaya untuk menanggulangi risiko yang dihadapi anggota masyarakat dan sekaligus merupakan salah satu lembaga penghimpun dana masyarakat, sehingga memiliki kedudukan strategis dalam pembangunan dan kehidupan perekonomian, dalam upaya memajukan kesejahteraan umum. Berikut ini adalah jenis-jenis dari usaha perasuransian;

1. Usaha Asuransi Umum

2. Usaha Asuransi Jiwa

3. Usaha Reasuransi

4. Usaha Asuransi Umum

5. Usaha Asuransi Jiwa Syariah

6. Usaha Reasuransi Syariah

7. Usaha Pialang Asuransi

8. Usaha Pialang Reasuransi

9. Usaha Penilai Kerugian Asuransi

10. Perusahaan Perasuransian

11. Perusahaan Asuransi

12. Perusahaan Asuransi Syariah

Undang-Undang Nomor 40 Tahun 2014 Tentang Perasuransian menggantikan Undang-Undang Nomor 2 Tahun 1992 Tentang Usaha Perasuransian. Secara umum, terdapat banyak perbedaan antara kedua undang-undang tersebut. Banyak ketentuan di undang-undang asuransi yang baru yang sebelumnya tidak diatur oleh undang-undang asuransi yang lama. Dari segi substansi, undang-undang asuransi yang baru mengatur lebih lengkap dibandingkan dengan undangundang asuransi yang lama dilihat dari jumlah rumusan pasal dan jumlah bab yang tercantum. Namun demikian, perbedaan yang paling signifikan antara kedua undang-undang tersebut di atas adalah peralihan fungsi pengaturan dan pengawasan terhadap asuransi dari Menteri Keuangan kepada Otoritas Jasa Keuangan (OJK). OJK berfungsi menyelenggarakan sistem pengaturan dan pengawasan yang terintegrasi terhadap keseluruhan kegiatan di dalam sektor jasa keuangan. ${ }^{36}$ OJK melaksanakan tugas pengaturan dan pengawasan tersebut terhadap: (i) kegiatan jasa keuangan di sektor Perbankan; (ii) kegiatan jasa keuangan di sektor Pasar Modal; dan (iii) kegiatan jasa keuangan di sektor Perasuransian, Dana

${ }^{36}$ Indonesia, Undang-Undang Otoritas Jasa Keuangan, UU No. 21 Tahun 2011, LN No. 111, TLN No. 5253, Ps. 5. 
Pensiun, Lembaga Pembiayaan, dan Lembaga Jasa Keuangan lainnya. ${ }^{37}$

Berdasarkan undang-undang, OJK resmi mengambil alih fungsi pengawasan perbankan dari Bank Indonesia sebagai bank sentral dan pengawasan sektor jasa keuangan non-perbankan dari Badan Pengawas Pasar Modal dan Lembaga Keuangan (BapepamLK). OJK berfungsi menyelenggarakan sistem pengaturan dan pengawasan yang terintegrasi terhadap keseluruhan kegiatan di dalam sektor jasa keuangan. ${ }^{38}$ OJK melaksanakan tugas pengaturan dan pengawasan tersebut terhadap: (i) kegiatan jasa keuangan di sektor Perbankan; (ii) kegiatan jasa keuangan di sektor Pasar Modal; dan (iii) kegiatan jasa keuangan di sektor Perasuransian, Dana Pensiun, Lembaga Pembiayaan, dan Lembaga Jasa Keuangan lainnya. ${ }^{39}$

Berdasarkan undang-undang, OJK resmi mengambil alih fungsi pengawasan perbankan dari Bank Indonesia sebagai bank sentral dan pengawasan sektor jasa keuangan non-perbankan dari Badan Pengawas Pasar Modal dan Lembaga Keuangan (BapepamLK). Otoritas Jasa Keuangan diharapkan dapat membuat kebijakan pengaturan dan pengawasan terhadap perasuransian yang dapat membawa perasuransian menjadi lebih berkembang di masa depan dan dapat menyaingi negara-negara maju dalam hal asuransi.

Setiap usaha perasuransian yang tidak mematuhi peraturan yang ditentukan dalam Undang-undang Nomor 40 tahun 2014 tentang Perasuransian, maka hal tersebut termasuk tindak pelanggaran. Yang termasuk kedalam unsur-unsur pelanggaran Usaha Perasuransian, yaitu:

${ }^{37}$ Indonesia, Undang-Undang Otoritas Jasa Keuangan, UU No. 21 Tahun 2011, LN No. 111, TLN No. 5253, Ps. 6.

${ }^{38}$ Indonesia, Undang-Undang Otoritas Jasa Keuangan, UU No. 21 Tahun 2011, LN No. 111, TLN No. 5253, Ps. 5.

${ }^{39}$ Indonesia, Undang-Undang Otoritas Jasa Keuangan, UU No. 21 Tahun 2011, LN No. 111, TLN No. 5253 , Ps. 6 .
1. Setiap Orang yang menjalankan kegiatan usaha asuransi, usaha asuransi syariah, Usaha Reasuransi, atau Usaha Reasuransi Syariah tanpa izin usaha sebagaimana dimaksud datam Pasal 8 ayat (1).

2. Setiap Orang yang menjalankan kegiatan Usaha Pialang Asuransi atau Usaha Pialang Reasuransi tanpa izin usaha sebagaimana dimaksud dalam Pasal 8 ayat (1).

3. Setiap Orang yang menjalankan kegiatan Usaha Penilai Kerugian Asuransi tarpa izin usaha sebagaimana dimaksud dalam Pasal 8 ayat (1)

4. Anggota direksi, anggota dewan komisaris, atau yang setara dengan anggota direksi dan anggota dewan komisaris pada badan hukum berbentuk koperasi atau usaha bersama sebagaimana dimaksud dalam Pasal 6 ayat (1) huruf c, anggota dewan pengawas syariah, aktuaris perusahaan, auditor internal, Pengendali, atau pegawai lain dari Perusahaan Perasuransian yang dengan sengaja memberikan laporan, informasi, data, dan/ atau dokumen kepada Otoritas Jasa Keuangan sebagaimana dimaksud dalam Pasal 22 ayat (1) yang tidak benar, palsu, dan/atau menyesatkan.

5. Anggota direksi, anggota dewan komisaris, atau yang setara dengan anggota direksi dan anggota dewan komisaris pada badan hukum berbentuk koperasi atau usaha bersama sebagaimana dimaksud dalam Pasal 6 ayat (1) huruf c, anggota dewan pengawas syariah, aktuaris perusahaan, auditor internal, Pengendali, atau pegawai lain dari Perusahaan Perasuransian yang dengan sengaja memberikan informasi, dari, dan/atau dokumen kepada pihak yang berkepentingan sebagaimana dimaksud dalam Pasal 22 ayat (a) dan Pasal 46 ayat (21 yang tidak benar, palsu, dan/atau menyesatkan.

6. Setiap Orang yang dengan sengaja tidak memberikan informasi atau memberikan informasi yang tidak benar, palsu, dan / atau menyesatkan kepada Pemegang Polis, Tertanggung, atau Peserta sebagaimana dimaksud dalam Pasal 31 ayat (2).

7. Setiap Orang yarrg menggelapkan Premi atau Kontribusi sebagaimana dimaksud dalam Pasal 28 ayat (5) dan Pasal 29 ayat (4). 
8. Setiap Orang yang menggelapkan dengan cara mengalihkan, menjaminkan, mengagunkan, atau menggunakan kekayaan, atau melakukan tindakan lain yang dapat mengurangi aset atau menurunkan nilai aset Perusahaan Asuransi, Perusahaan Asuransi Syariah, perusahaan reasuransi, atau perusahaan reasuransi syariah sebagaimana dimaksud dalam Pasal 43 ayat (21).

9. Setiap Orang yang melakukan pemalsuan atas dokumen Perusahaan Asuransi, Perusahaan Asuransi Syariah, perusahaan reasuransi, atau perusahaan reasuransi syariah sebagaimana dimaksud dalam Pasal 33.

10. Anggota direksi dan/atau pihak yang menandatangani polis baru dari Perusahaan Asuransi atau Perusahaan Asuransi Syariah yang sedang dalam pengenaan sanksi pembatasan kegiatan usaha sebagaimana dimaksud dalam Pasal 34.

11. Setiap Orang, yang ditunjuk atau ditugasi oleh Otoritas Jasa Keuangan, yang menggunakan atau mengungkapkan informasi apapun yang bersifat rahasia kepada pihak lain, kecuali dalam rangka pelaksanaan fungsi, tugas, dan wewenangnya berdasarkan keputusan Otoritas Jasa Keuangan atau diwajibkan oleh undang-undang sebagaimana dimaksud dalam Pasal 67.

Setiap Perusahaan Perasuransian yang tidak memenuhi syarat dan perizinan mendirikan usaha perasuransian yang sesuai dengan ketentuan dalam Peraturan Undang-undang Nomor 40 Tahun 2014 tentang Perasuransian, maka akan dikenai sanksi hukuman. Sanksi hukuman bagi pelaku tindak pelanggarn usaha perasuransian ada 2 ketentuan yakni;

\section{Sanksi Administratif}

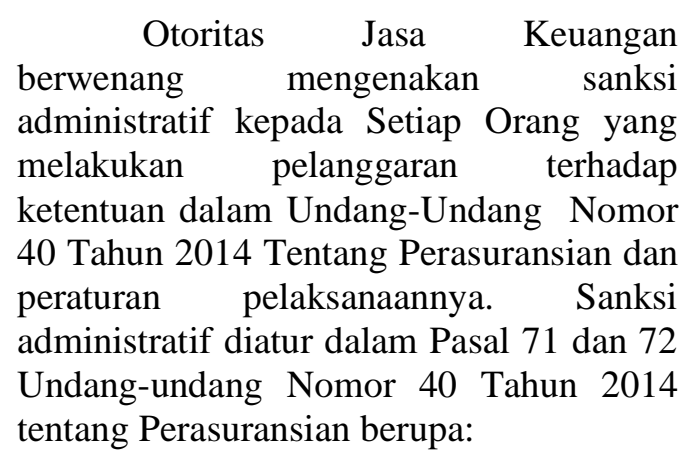

a. Peringatan tertulis;

b. Pembatasan kegiatan usaha, untuk sebagian atau seluruh kegiatan usaha;

c. Larangan untuk memasarkan produk asuransi atau produk asuransi syariah untuk lini usaha tertentu;

d. Pencabutan izin usaha;

e. Pembatalan pemyataan pendaftaran bagi Pialang Asuransi, Pialang Reasuransi, dan Agen Asuransi;

f. Pembatalan pernyataan pendaftaran bagi konsultan alrtuaria, akuntan publik, penilai, atau pihak lain yang memberikan jasa bagi Perusahaan Perasuransian;

g. Pembatalan persetujuan bagi lembaga mediasi atau asosiasi;

h. Denda administratif; dan/ atau

i. Larangan menjadi pemegang saham, Pengendali, direksi, dewan komisaris, atau yang setara dengan pemegang saham, Pengendali, direksi, dan dewan komisaris pada badan hukum berbentuk koperasi atau usaha bersama sebagaimana dimaksud dalam Pasal 6 ayat (1) huruf $\mathrm{c}$, dewan pengawas syariah, atau menduduki jabatan eksekutif di bawah direksi, atau yang setara dengan jabatan eksekutif di bawah direksi pada badan hukum berbentuk koperasi atau usaha bersama sebagaimana dimaksud da-lam Pasal 6 ayat (1) huruf c, pada Perusahaan Perasuransian.

Dalam hal Otoritas Jasa Keuangan menilai kondisi Perusahaan Perasuransian membahayakan kepentingan Pemegang Polis, Tertanggung, atau Peserta, Otoritas Jasa Keuangan dapat mengenakan sanksi pencabutan izin usaha tanpa didahului pengenaan sanksi administratif yang lain.

2. Sanksi Pidana

Sanksi Pidana dikenakan pada kejahatan perasuransian yang diatur dalam Undang-undang Nomor 40 Tahun 2014 tentang Perasuransian. Menurut Pasal 73 Undang-undang Nomor 40 Tahun 2014 tentang Perasuransian, yakni:

1. Setiap Orang yang menjalankan kegiatan usaha asuransi, usaha asuransi syariah, Usaha Reasuransi, atau Usaha Reasuransi Syariah tanpa izin usaha sebagaimana dimaksud 
dalam Pasal 8 ayat (1) dipidana dengan pidana penjara paling lama 15 (lima belas) tahun dan pidana denda paling banyak Rp200.000. 000.000,00 (dua ratus miliar rupiah).

2. Setiap Orang yang menjalankan kegiatan Usaha Pialang Asuransi atau Usaha Pialang Reasuransi tanpa izin usaha sebagaimana dimaksud dalam Pasal 8 ayat (1) dipidana dengan pidana penjara paling lama 10 (sepuluh) tahun dan pidana denda paling banyak Rp3.000.000.000,00 (tiga miliar rupiah).

3. Setiap Orang yang menjalankaa kegiatan Usaha Penilai Kerugian Asuransi tarpa izin usaha sebagaimana dimaksud dalam Pasal 8 ayat (1) dipidana dengan pidana penjara paling lama 3 (tiga) tahun dan pidana denda paling banyak Rp1.000.000.000,00 (satu miliar rupiah).

Menurut Pasal 74 Undang-undang Nomor 40 Tahun 2014 tentang Perasuransian, yakni:

1. Anggota direksi, anggota dewan komisaris, atau yang setara dengan anggota direksi dan anggota dewan komisaris pada badan hukum berbentuk koperasi atau usaha bersama sebagaimana dimaksud dalam Pasal 6 ayat (1) huruf c, anggota dewan pengawas syariah, aktuaris perusahaan, auditor internal, Pengendali, atau pegawai lain dari Perusahaan Perasuransian yang dengan sengaja memberikan laporan, informasi, data, dan/ atau dokumen kepada Otoritas Jasa Keuangan sebagaimana dimaksud dalam Pasal 22 ayat (l) yang tidak benar, palsu, dan/atau menyesatkan dipidana dengan pidana penjara paling lama 5 (lima) tahun dan pidana denda paling banyak Rp10.000.000.000,00 (sepuluh miliar rupiah).

2. Anggota direksi, anggota dewan komisaris, atau yang setara dengan anggota direksi dan anggota dewan komisaris pada badan hukum berbentuk koperasi atau usaha bersama sebagaimana dimaksud dalam
Pasal 6 ayat (1) huruf c, anggota dewan pengawas syariah, aktuaris perusahaan, auditor internal, Pengendali, atau pegawai lain dari Perusahaan Perasuransian yang dengan sensaja memberikan informasi, data, dan/atau dokumen kepada pihak yang berkepentingan sebagaimala dimaksud dalam Pasal 22 ayat (a) dan Pasal 46 ayat (21 yang tidak benar, palsu, dan/atau menyesatkan dipidana dengan pidana penjara paling lama 5 (lima) tahun dan pidana denda paling banyak Rp20.000.000.000,00 (dua puluh miliar rupiah).

Menurut Pasal 75 Undang-undang Nomor 40 Tahun 2014 tentang Perasuransian, yakni:

"Setiap Orang yang dengan sengaja tidak memberikan informasi atau memberikan informasi yang tidak benar, palsu, dan / atau menyesatkan kepada Pemegang Polis, Tertanggung, atau Peserta sebagaimana dimaksud dalam Pasal 31 ayat (2) dipidana dengan pidana penjara paling lama 5 (lima) tahun dan pidana denda paling banyak Rp5.000.000.000,00 (lima miliar rupiah)".

Menurut Pasal 76 Undang-undang Nomor 40 Tahun 2014 tentang Perasuransian, yakni:

"Setiap Orang yarrg menggelapkan Premi atau Kontribusi sebagaimana dimaksud dalam Pasal 28 ayat (5) dan Pasal 29 ayat (4) dipidana dengan pidana penjara paling lama 5 (Iima) tahun dan pidana denda paling banyak Rp5.000.000.000,00 (lima miliar rupiah)".

Menurut Pasal 77 Undang-undang Nomor 40 Tahun 2014 tentang Perasuransian, yakni:

"Setiap Orang yang menggelapkan dengan cara mengalihkan, menjaminkan, mengagunkan, atau menggunakan kekayaan, atau melakukan tindakan lain yang dapat mengurangi aset atau menurunkan nilai aset Perusahaan 
Asuransi, Perusahaan Asuransi Syariah, perusahaan reasuransi, atau perusahaan reasuransi syariah sebagaimana dimaksud dalam Pasal 43 ayat (21 tanpa hak dipidana dengan pidana penjaranpaling lama 8 (delapan) tahun dan pidana denda paling banyak Rp50.000.000.000,00 (lima puluh miliar rupiah).

Menurut Pasal 78 Undang-undang Nomor 40 Tahun 2014 tentang Perasuransian, yakni:

"Setiap Orang yang melakukan pemalsuan atas dokumen Perusahaan Asuransi, Perusahaan Asuransi Syariah, perusahaan reasuransi, atau perusahaan reasuransi syariah sebagaimana dimaksud dalam Pasal 33 dipidana denganpidana penjara paling lama 6 (enam) tahun dan pidana denda paling banyak Rp5.000.000.000,00 (lima miliar rupiah)".

\section{Menurut Pasal 79 Undang-undang Nomor 40 Tahun 2014 tentang Perasuransian, yakni:}

"Anggota direksi dan/atau pihak yang menandatangani polis baru dari Perusahaan Asuransi atau Perusahaan Asuransi Syariah yang sedang dalam pengenaan sanksi pembatasan kegiatan usaha sebagaimana dimaksud dalam Pasal 34 dipidana dengan pidana penjara paling lama 5 (lima) tahun dan pidana denda paling banyak Rp15.000.000.000,00 (lima belas miliar rupiah)".

Menurut Pasal 80 Undang-undang Nomor 40 Tahun 2014 tentang Perasuransian, yakni:

"Setiap Orang, yang ditunjuk atau ditugasi oleh Otoritas Jasa Keuangan, yang menggunakan atau mengungkapkan informasi apapun yang bersifat rahasia kepada pihak lain, kecuali dalam rangka pelaksanaan fungsi, tugas, dan wewenangnya berdasarkan keputusan Otoritas Jasa Keuangan atau diwajibkan oleh undang-undang sebagaimana dimaksud dalam Pasal 67, dipidana dengan pidana penjara paling lama 5 (lima) tahun dan pidana denda paling banyak Rp20. 000. 000.000,00 (dua puluh miliar rupiah)".

Menurut Pasal 81 Undang-undang Nomor 40 Tahun 2014 tentang Perasuransian, yakni:

1. Dalam hal tindak pidana sebagaimana dimaksud dalam Pasal 73, Pasal 75, Pasal 76, Pasal 77, Pasal 78, atau Pasal 80 dilakukan oleh korporasi, pidana dijatuhkan terhadap korporasi, Pengendali, dan/atau pengurus yang bertindak untuk dan atas nama korporasi.

2. Pidana dijatuhkan terhadap korporasi apabila tindak pidana:

a. Dilakukan atau diperintahkan oleh Pengendali dan/atau pengurus yang bertindak untuk dan atas nama korporasi;

b. Dilakukan dalam rangka pemenuhan maksud dan tujuan korporasi;

c. Dilakukan sesuai dengan tugas dan fungsi pelaku atau pemberi perintah; dan dilakukan dengan maksud memberikan manfaat bagi korporasi.

Menurut Pasal 82 Undang-undang Nomor 40 Tahun 2014 tentang Perasuransian, yakni:

"Pidana yang dijatuhkan terhadap korporasi adalah pidana denda paling banyak Rp600.000.000.000,00 (enam ratus miliar rupiah)".

Sanksi hukuman diberikan untuk mengatur kehidupan kemasyarakatan atau menyelenggarakan tata dalam masyarakat yang berfungsi sebagai sarana dalam penanggulangan kejahatan atau sarana kontrol sosial atau pengendalian masyrakat. Karena sifat sanksinya yang memberikan penderitaan inilah dianggap 
sebagai ultimum remidium atau obat untuk dapat menanggulangi perbuatan yang merugikan dan tentunya membuat pelaku pelanggaran pada usaha perasuransian jera, sehingga tidak mengulangi perbuatan tersebut.

Sanksi hukum terhadap pelaku tindak pelanggaran usaha perasuransian menurut Undang-undang Nomor 40 Tahun 2014 tentang Perasuransian sangatlah jelas, jika usaha perasuransian melakukan pelanggaran terhadap ketentuan undangundang atau peraturan dalam pelaksanaannya maka Otoritas Jasa Keuangan berwenang melakukan tindakan berupa pemberian peringatan, pembatasan kegiatan usaha, larangan untuk memasarkan produk asuransi, memberi sanksi-sanksi pidana hingga pada pencabutan izin usaha.

\section{PENUTUP} yaitu:

Kesimpulan yang dapat diambil

1. Pengaturan Usaha Perasuransian yang dimuat dalam undang-undang Nomor 40 tahun 2014 Tentang Perasuransian, serta di tunjuknya Otoritas Jasa Keuangan (OJK) sebagai lembaga negara yang memiliki kuasa penuh dalam menjalankan fungsi dan pengawasan meliputi perizinan usaha perasuransian, tata kelola penyelenggaraan perasuransian, pergantian pemilikan, penggabungan, dan peleburan, serta sampai pada pembubaran, likuidasi, dan kepailitan dalam dunia perasuransian yang ada di Indonesia, diharapkan dapat membuat kebijakan dalam pengaturan dan pengawasan terhadap perasuransian yang dapat membawa perasuransian menjadi lebih berkembang di masa depan dan dapat bersaing dengan negara-negara maju dalam dunia asuransi.

2. Sanksi hukum terhadap pelaku tindak pelanggaran usaha perasuransian menurut Undang-undang Nomor 40 Tahun 2014 tentang Perasuransian sangatlah jelas, jika usaha perasuransian melakukan pelanggaran terhadap ketentuan undang-undang atau peraturan dalam pelaksanaannya maka Otoritas Jasa Keuangan berwenang melakukan tindakan berupa pemberian peringatan, pembatasan kegiatan usaha, larangan untuk memasarkan produk asuransi, memberi sanksi-sanksi pidana hingga pada pencabutan izin usaha. adalah:

Sedangkan saran yang dapat diajukan

1. Perusahaan Asuransi wajib melihat, memperhatikan, serta melaksanakan aturan Undang-undang yang ditetapkan pemerintah dalam proses pembentukan Usaha Perasuransiannya dan Perusahaan Asuransi dalam perjalanan usahanya wajib mematuhi jalannya usaha sesuai ketentuanketentuan yang ada di Pemerintah Republik Indonesia.

2. Nasabah Asuransi haruslah lebih cermat dan berhati-hati dalam memilih perusahaan asuransi, agar nantinya nasabah tidak sebagai korban melainkan, merasa terlindungi dan nyaman akan kemungkinan resikoresiko yang timbul dikemudian hari.

\section{E. DAFTAR PUSTAKA}

\section{Daftar Kepustakaan}

\section{Grafika, Sinar. "Undang-Undang Perasuransian (Undang-undang Republik Indonesia No.40 Tahun 2014)" Jakarta, Penerbit Sinar Grafika, 2015}

Ibrahim, Johnny. "Teori dan Metodologi Penelitian hukum Normatif", cetakan ke enam, Malang, Bayumedia Publishing. 2012.

Marzuki, Peter Mahmud. "Penelitian Hukum”. Surabaya. Universitas Air Langga. 2005. 
Moeljatno, "Kitab Undang-Undang Pidana" Yogyakarta, Penerbit Bumi Aksara, 1999

Muhammad, Abdul Kadir, "Hukum Asuransi Indonesia”, Bandung, PT.Citra Aditya Bakti. 1998.

Salim, Abbas. 1998. "Asuransi \& Manajemen Risiko", Jakarta, Cetakan ke-10, Rajawali Pers. 2012

Sembiring, Sentosa "Hukum Asuransi", Bandung, Cetakan pertama, Nuansa Aulia, 2014.

\section{Sumber Internet}

Glosarium,"Pelanggaran", http://glosarium.org/arti/?k=pelangga ran diunduh pada 03 Juni 2015.

Indonesia, "Undang-Undang No 3 Tahun 1992 Tentang Usaha

Perasuransian", http://www.google.co.id/url?sa=t \&rct $=\mathrm{j} \& \mathrm{q}=$ undangundang\%20usaha\%20perasuransi an\%2C\%20uu\%20no.\%202\%20ta hun\%201992\&source $=$ web\&cd $=1$ $\&$ cad $=$ rja \&uact $=8 \&$ ved $=0$ CCAQ FjAAahUKEwiry53p74vGAhWJf 7wKHScbAJA\&url=http $\% 3 \mathrm{~A} \% 2$ F\%2Fwww.hukumonline.com\%2 Fpusatdata\%2Fdownloadfile\%2Fl t4c3d4dbb15cd4\%2Fparent $\% 2 \mathrm{~F} 3$ 987\&ei=ALd7VevLLon_8QWnto CACQ\&usg=AFQjCNEHUv64C C9maiCtXPbrcj0LMWDc_Q\&bv $\mathrm{m}=$ bv.95515949,d.dGc (www.hukumonline.com) diunduh pada 05 Juni 2015.

Indonesia, "Undang-Undang No. 3 Tahun 2004 Tentang Perubahan Atas
Undang-Undang Nomor 23 Tahun 1999 Tentang Bank Indonesia", www.bi.go.id/id/tentang-bi/uubi/Documents/uu bi no0304.pdf. diunduh pada 02 Juni 2015.

Indonesia, “Undang-Undang No. 21 Tahun 2011 Tentang Otoritas Jasa Keuangan”, www.bapepam.go.id/bapepamlk/o thers/UU-21-2011-OJK.pdf, diunduh pada 01 Juni 2015

Lisa, “ Tindak Pidana Penipuan” http://makalah-hukumpidana.blogspot.com/2011/04/tind ak-pidana-penipuan.html diunduh pada 01 Juni 2015.

Mamiko Yokoi-Arai, "The Regulatory Efficiency of a Single Regulator in Financial Services: Analysis of the UK and Japan", Banking and Finance Law Review, (Oktober 2006), http://ditjenpp.kemenkumham.go.id/f iles/doc/2373_JLI\%20Vol.\%209\%20 No.\%203.pdf diunduh pada 04 Juni 2015

Wikipedia, "Asuransi" http://id.wikipedia.org/wiki/Asuransi . di unduh pada 02 Juni 2015.

Zulkarnain Sitompul, "Konsepsi dan Transformasi Otoritas Jasa Keuangan", Journal Legislasi Indonesia Vol. 9 No. 3 (Oktober 2012), hlm. 345. http://www.academia.edu/942629 9/Sekadar_Perbandingan_UU_No .40_Tahun_2014 tentang_Peras uransian_dengan_UU_No._2_Tah un 1992 tentang Usaha Perasur ansian diunduh pada 02 Juni 2015. 
"Definisi

https://deden08m.files.wordpress.co $\mathrm{m} / 2011 / 09 /$ materi-7asuransi-

rm.pdf.di unduh pada 18 Juni 2009.

\section{Perundang-undangan}

Undang - undang nomor 40 tahun 2014

tentang Perasuransian

Undang - undang nomor 2 tahun 1992 tentang

Usaha Perasuransian

Wetboek van Koophandel voor Indonesia (W

v K) atau Kitab Undang-undang Hukum Dagang dan kitab undang-undang hukum pidana (KUHP) 